ำ

㟧

絮出

$E \geq z$ 낭

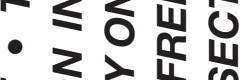

-

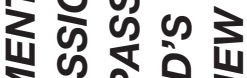

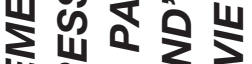

II $\frac{1}{4}$

의 웅

\& $\frac{1}{\alpha}$ \&

인 능

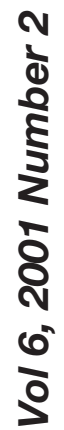

I T

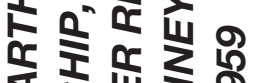

ธ

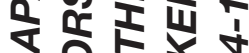

$10 \leqslant<4$

E

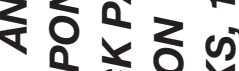

แ क ज $\frac{0}{\mathbb{\alpha}}$

I $25 \frac{1}{2}$

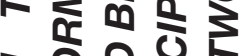

운요

山 $\frac{1}{\infty} \leqslant$

ज山

उ

웅 क

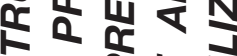

$\omega \geqslant \frac{1}{2}$

- 0 뜬

난

๙

$<30 \frac{1}{5}$

उ

○ ₹

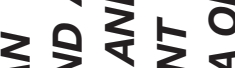

小娄

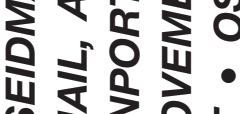

ஸ $\frac{1}{2}$ ய

iن

क $₹ \mathbb{a} \leqslant$

๘)・

ง

\%

E

३

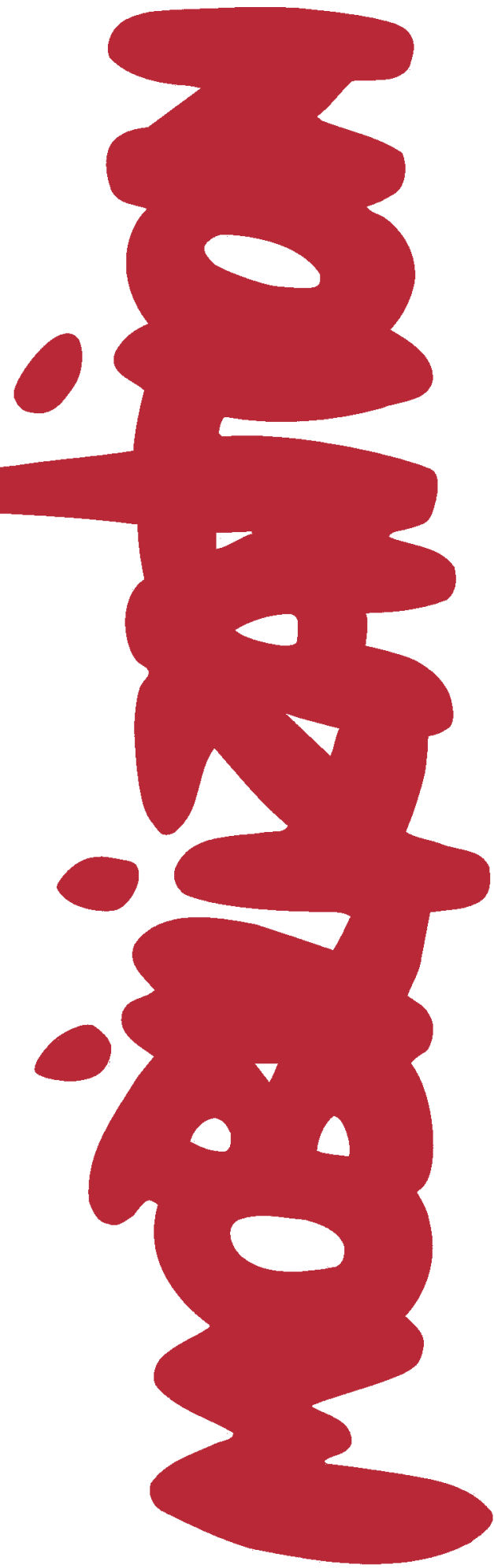




\section{MOBILIZATION}

The International Journal of Research and Theory about Social Movements, Protest, and Contentious Politics

\section{Editor}

Hank Johnston, San Diego State University

European Editor

Mario Diani, University of Trento

Book Review Editor

David Meyer, University of California, Irvine

\section{Associate Editors}

Jeffrey Broadbent, University of Minnesota

Barbara Cottrell, University of California, Riverside

Sebastian Haunss, University of Hamburg

Heidi Swarts, Syracuse University

\section{Assistant Editor}

\section{Maureen Steinel, San Diego State University}

\section{Editorial Advisory Board}

François Chazel, Université de Paris-Sorbonne Donatella della Porta,Università degli Studi di Firenze Wanda Dressler, Université de Nanterre

Ron Eyerman, Uppsala University, Sweden Bill Gamson, Boston College

Joseph Gusfield, University of California, San Diego

Koichi Hasegawa, Tohoku University

Craig Jenkins, Ohio State University

Jane Jenson, Université de Montréal

Mary Katzenstein, Cornell University

Bert Klandermans, Free University, Amsterdam

Hanspeter Kriesi, Université de Genève

Enrique Laraña, Universidad Complutense de Madrid

Doug McAdam, Stanford University

John McCarthy, Pennsylvania State University

Clark McPhail, University of Illinois

Margit Mayer, Freie Universität Berlin

Louis Maheu, Université de Montréal

Alberto Melucci, Università degli Studi di Milano

Janusz Mucha, Copernicus University, Warsaw

Carol Mueller, Arizona State University

\author{
Anthony Oberschall, University of North Carolina \\ Pamela Oliver, University of Wisconsin \\ Johan Olivier, Human Sciences Research Council, Pretoria \\ T.K. Oommen, Jawaharalal Nehru University, New Delhi \\ Karl Dieter Opp, Universität Leipzig \\ Christopher Rootes, University of Kent \\ Roland Roth, Fachhochscule Madeburg \\ Dieter Rucht, University of Kent \\ Martti Siisiäinen, University of Jyväskylä, Finland \\ David Snow, University of Arizona \\ Suzanne Staggenborg, McGill University \\ Judith Stepan-Norris, University of California, Irvine \\ Máté Szabó, Etvös Loránd University, Budapest \\ Piotr Sztompka, Jagiellonian University, Cracow \\ Verta Taylor, Ohio State University \\ Sidney Tarrow, Cornell University \\ Benjamín Tejerina, Universidad del Pais Vasco \\ Charles Tilly, Columbia University \\ Ralph Turner, University of California, Los Angeles \\ Mayer Zald, University of Michigan \\ Ekkart Zimmermann, Technische Universität Dresden
}




\section{MOBILIZATION}

The International Journal of Research and Theory about Social Movements, Protest, and Contentious Politics

\section{Articles}

Guerrillas in their Midst: Armed Struggle in the South African Anti-Apartheid Movement

Gay Seidman

The Interaction of State Repression, Protest Form and Protest Sponsor Strength During the Transition from Communism in Minsk, Belarus, 1990-1995

Larissa Titarenko, John D. McCarthy,

Clark McPhail, and Boguslaw Augustyn

Cued to Coerce or Coercing Cues?

An Exploration of Dissident Rhetoric and its Relationship

to Political Repression

Christian Davenport and Marci Eads

Socialization, Connection, and the Structure/Agency Gap:

A Specification of the Impact of Networks on Participation in Social Movements

Florence Passy

Framing, Political Opportunities, and Civic Mobilization in the

Eastern European Revolutions: A Case Study of Poland's Freedom and Peace Movement

Padraic Kenney

Mobilizing Structures and Cycles Of Protest:

Post-Stalinist Contention in Poland, 1954-1959

Maryjane Osa 


\section{Book Reviews}

Nancy A. Naples,

Grassroots Warriors; Activist Mothering, Community Work, and the War

on Poverty.

Reviewed by Mary Fainsod Katzenstein $\ldots \ldots$. . . . . . . . . . . 233

Rebecca E. Klatch,

A Generation Divided: The New Left, The New Right, and The 1960s.

Reviewed by Deana A. Rohlinger . . . . . . . . . . . . . . . . . . . . 234

Paul C. Mishler,

Raising Reds: The Young Pioneers, Radical Summer Camps,

and Communist Political Culture in the United States.

Reviewed by Rachel L. Einwohner . . . . . . . . . . . . . . . . . 235

Marc W. Steinberg,

Fighting Words. Working-Class Formation, Collective Action, and

Discourse in Early Nineteenth Century England.

Reviewed by Colin Barker . . . . . . . . . . . . . . . . . . . . 236

David Zaret,

Origins of Democratic Culture: Printing, Petitions, and the Public

Sphere in Early-Modern England.

Reviewed by Michael Hanagan . . . . . . . . . . . . . . . . . . . 237

Jeffrey Broadbent,

Environmental Politics in Japan: Networks of Power and Protest.

Reviewed by Patricia G. Steinhoff . . . . . . . . . . . . . . . . . . . 238

Sylvia Noble Tesh,

Uncertain Hazards: Environmental Activists and Scientific Proof.

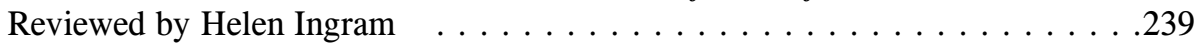

Cynthia L. Irvin,

Militant Nationalism. Between Movement and Party in Ireland

and the Basque Country.

Reviewed by Jesús Casquette . . . . . . . . . . . . . . . . . . . . . . 240

Dieter Rucht, Ruud Koopmans, and Friedhelm Neidhart, Editors.

Acts of Dissent: New Developments in the Study of Protest.

Reviewed by Philip N. Cohen 


\title{
SOCIALIZATION, CONNECTION, AND THE STRUCTURE/AGENCY \\ GAP: A SPECIFICATION OF THE IMPACT OF NETWORKS ON \\ PARTICIPATION IN SOCIAL MOVEMENTS*
}

\author{
Florence Passy ${ }^{\dagger}$
}

\begin{abstract}
While numerous studies stress the crucial role of networks for social movement participation, they generally do not specify how networks affect individual behaviors. This article clarifies the role of social networks for individual social movement participation. It argues that networks perform three fundamental functions in the process leading to participation and that they intervene at different moments along this process. First, networks socialize and build individual identities-a socialization function. Second, they offer participation opportunities to individuals who are culturally sensitive to a specific political issue-a structural-connection function. Third, they shape individual preferences before individuals decide to join a movement-a decision-shaping function. These network functions allow us to disentangle the mechanisms at work in the process of participation. They also integrate structural and rationalist theories, which are often considered opposing explanations of individual movement participation. This article presents several hypotheses about these network functions, and uses both quantitative (survey) and qualitative (life history) data of participation in the Berne Declaration SMO to examine them.
\end{abstract}

In the desert of sand, like elsewhere, there is no neutral encounter.

Georges Haldas

Much social movement research stresses the crucial role of networks for movement emergence and development (della Porta 1988, 1995; Diani 1995; Fernandez and McAdam 1989; Friedman and McAdam 1992; Gould 1995; Klandermans 1997; Klandermans and Oegema 1987; Oberschall 1973, 1993; Marwell and Oliver 1993; McAdam 1982, 1988; McAdam and Paulsen 1993; Rosenthal et al. 1985; Snow et al. 1980). In particular, social networks are shown to be crucial to recruitment and participation of individuals. However, this research often overlooks the various ways that networks affect individual behaviors, and rarely goes beyond simple acknowledgement that an individual's previous insertion in social networks affect their participation. Marwell, Oliver, and Prahl (1988) also note the uncontested importance of networks for participation, and observe that knowledge of how networks influence individual participation is quite limited. McAdam and Paulsen (1993: 641) similarly state that "while [networks] remain important, these studies are nonetheless plagued by a troubling theoretical and empirical imprecision that raises important questions about their ultimate utility." In particular, there has never been a detailed examination of the multiple functions that networks play in the participation process.

\footnotetext{
* I thank Doug McAdam for his constructive comments on previous drafts of the paper. I am also grateful for helpful suggestions of Hank Johnston and Mobilization's anonymous reviewers.

$\dagger$ Florence Passy is Assistant Professor of Political and International Studies, University of Lausanne, Switzerland. E-mail: florence.passy@iepi.unil.ch.
}

๑ Mobilization: An International Journal, 2001, 6(2): 173-192 
A number of recent studies offer a deeper understanding of the impact of social relations on individual participation by specifying the nature of network ties (Kim and Bearman 1997; Gould 1993, 1995; Heckathorn 1993; McAdam and Paulsen 1993; Marwell and Oliver 1993). Yet many questions remain unanswered. Specifically, we do not know how networks intervene in the process of individual mobilization. If the multiple functions of social networks remain vague and confused, we face an even more problematic situation with respect to the impact of networks on decision to join a movement. We know little about the ways in which social networks shape individual perceptions. Yet, this function of networks is important because it links social structures to human agency (Emirbayer and Goodwin 1994) and reconciles structural and rationalist explanations of individual participation.

We can distinguish between two different traditions in the literature that have pointed out the role of social interactions in social movement participation. First, scholars who have looked at the role of social structures in social movements have stressed two different network functions. On the one hand, some have put forward what I call the socialization function of networks. Participation in social movements is seen as an identification process (e.g., Andrew 1991; Calhoun 1989; Fernandez and McAdam 1989; Freeman 1973; McAdam 1982; McAdam and Paulsen 1993; Morris 1984; Melucci 1996; Whittier 1995). People engage in collective action because they share certain norms and values with a specific social movement. Participation, in turn, helps them to define a collective identity. Since identities are created and shaped through social relations, networks play a crucial role in the process of individual participation. On the other hand, scholars have emphasized the structural-connection function of networks. Networks help connect potential participants to opportunities for mobilization. Many studies have shown that individuals who have friends or acquaintances who are already involved in social movements are more inclined to participate (e.g. della Porta 1988, 1995; Gould 1993, 1995; Klandermans 1997; Kriesi 1993; McAdam 1986, 1988; Snow et al. 1980). Networks bridge the structural gap between individuals and social movements, and thus bring people closer to opportunities for mobilization.

A second line of research has pointed to the role of networks for individual participation, but from a very different perspective. Rational choice theorists stress the impact of individual preferences and perceptions on collective action (e.g. Chong 1990; Macy 1991; Marwell and Oliver 1993; Mueller and Opp 1986; Olson 1965; Opp 1989; Sandler 1992). Several scholars in the rational choice tradition have criticized the assumption made in collective action modeling that individuals take isolated and autonomous decisions; and have proposed to take into account social interactions to explain movement participation. Gerald Marwell and Pamela Oliver have been among the first to combine individual choice models with relational variables (Marwell and Oliver 1993; Marwell et al. 1988; Oliver 1984; Oliver et al. 1985; Oliver et al. 1988). Following their lead, others have taken into account the role of social interactions and the interdependence of actors (e.g., Heckathorn 1993; Kim and Bearman 1997; Macy 1991; Opp 1989). They have shown that the decision to join a collective action is influenced by the action of other participants. This research tradition stresses the role of networks in the definition of individual perceptions, a function that I call the decisionshaping function of networks.

More generally, rational choice scholars stress that social interactions strongly shape perceptions in the short term, such as the perception of the chances of success of the protest, of the number of participants already mobilized, of the risk involved in participation, of the effectiveness of one's own participation in a specific campaign or organization, and so forth. These perceptions are particularly volatile and shape the individual decisions about joining a social movement. This function has to be distinguished from the socialization function of networks put forward by structuralists, who emphasize the role of social interactions-specifically, the embeddedness in formal or informal networks-in the construction or solidification 
of norms, values, and identities related to the protest. Norms, values, and identities are also perceptions, but they are fairly stable over time. Network embeddedness contributes to the creation of norms and identities that construct a political consciousness for a specific political issue; that is, an individual disposition to join a social movement. For example, embeddedness in African-Americans churches helped shape the political consciousness for southern blacks (McAdam 1982, Morris 1984). Similarly, the involvement in radical leftist groups helped many women to become aware of women's emancipation (Freeman 1973). While structuralist and rationalist traditions both stress the role of social interactions in the construction of individual perceptions, these two functions, as we shall see in more detail below, intervene at different stages of the process of individual participation.

Only a few scholars outside the rationalist tradition have also pointed out—often less explicitly-the impact of networks on participation decisions. ${ }^{1}$ Doug McAdam (1982) has gone farthest in specifying network's decision-shaping functions, and more recently has elaborated a microstructural model of participation based on four conditions: "(1) the occurrence of a specific attempt, (2) the conceptualization of a tentative linkage between movement participation and identity, (3) support for that linkage from persons who normally serve to sustain the identity in question, and (4) the absence of strong opposition from others on whom other salient identities depend" (McAdam and Paulsen 1993: 647). Here, the ultimate decision to participate is closely related to individual identities. People will join a social movement if this decision resonates with their identities, if someone can sustain their mobilization identity, and if there is not countervailing identity. In McAdam and Paulsen's model, however, the decisional parameters underscored by rationalists, such as the effectiveness of the collective action or the risks involved in participation, are overlooked. In other words, their microstructural recruitment model emphasizes relational structures but ignores human agency.

The issue of human agency is crucial to a network theory of participation. Structuralist explanations tend to neglect the role of human agency and the ways in which actors make sense of their multiple social interactions. Individuals incorporate past and present interactions into their self concept. This process of incorporation, as Emirbayer and Goodwin (1994) have pointed out, allows social actors to express their own creativity. As a consequence, individual action is more than simply a reflection of social structures. It is a social construction largely determined by one's capacity to make sense of everyday-life interactions. Structuralist accounts underestimate how human agency incorporates symbols and discourses in individual practices. McAdam and Paulsen (1993) have tried to avoid this problem by specifying the relationship between social ties and activism. However, they overlook individual preferences in favor of a theory that stresses the impact of identities.

The rationalist tradition, on the other hand, has its own weaknesses regarding agency. First, it looks only at one end of the process that leads to collective action, namely the moment when one decides to join a movement. Yet participation in social movements usually begins with a phase of socialization to political issues and identity building that creates what McAdam and Paulsen (1993: 647) call "initial dispositions to participate." In this initial phase, social networks play an important role neglected by most scholars in this tradition. While individual perceptions are seen as volatile and subject to external influences, it is assumed that the interest in a specific political issue is given and fixed (but see Kim and Bearman 1997 for an exception). Thus rationalist models tend to be ahistorical in the sense that they do not take into account the life history of individuals. They do not examine how individuals develop a strong attachment to a political issue, a process that takes place before individuals decide to join collective action and in which networks play a crucial role. Second,

1 For example, in a perspective similar to that of critical mass theorists, Klandermans $(1984,1997)$ has considered the interdependence of actors in the process of joining collective action, but following a social-psychological approach. 
the rationalist tradition conveys an instrumentalist conception of networks. For example, the critical mass theory postulates that individuals decide whether they will participate by looking at other people's behaviors, which allow them to anticipate the costs and potential outcomes of protest. Here the impact of social networks is too narrowly conceptualized in terms of their instrumental role, overlooking the construction of meanings arising from social interactions.

This article attempts to redress these two weaknesses in the structural and rationalist perspectives. Individual calculations are certainly fundamental in the decision to participate, but these decisions are not taken in a social vacuum. Quite the contrary, they are strongly shaped by their interactions with other actors as prospective participants incorporate and make sense of their multiple social interactions according to their past experiences, present feelings, and future hopes and projects. This process represents a moment of freedom whereby social structures are not only reproduced but also transformed (Emirbayer and Goodwin 1994). Social networks are constructed realities or, as Harrison White (1992: 65) has put it, "phenomenological realities as well as measurement constructs." In other words, "a social network is a network of meanings" (White 1992: 67) which influences and transforms the individual perceptions that are at the origin of the actors' decision.

Social networks are a key concept for bridging the structure-agency gap. On the one hand, network structures and interactions provide individuals with cultural resources that they may use to join in collective actions. On the other hand, social networks, as islands of meanings, shape individual perceptions that form the basis for the ultimate decision to participate. The principle aim of this article is to specify the concept of social networks and to show how networks intervene at different moments and with distinct functions in the process of individual participation in social movements. I will focus on three functions: (1) social networks socialize individuals to certain political issues; (2) they structurally connect individuals who are willing to participate in a mobilization opportunity (e.g., a social movement organization); and (3) they shape individual perceptions. The first function contributes to the formation of dispositions to participate; the second brings prospective participants closer to a social movement organization (or some other mobilization opportunity); and the third shapes individual perceptions and preferences pertaining to collective action, and hence leads to the ultimate decision to participate.

\section{STUDYING MULTIPLE NETWORK FUNCTIONS: TWO COMPLEMENTARY METHODS}

To shed light on the role of networks in different aspects of individual participation, I use both quantitative and qualitative data-a rare combination in social movement research. The quantitative data stem from a survey of 646 randomly selected members of an organization of the Swiss solidarity movement, the Bern Declaration. The solidarity movement focuses on four basic issues: development aid, immigration and asylum, human rights, and antiracism. One of its peculiarities lies in the fact that people mobilize on behalf of others (for an extensive discussion see Passy 1998; and Giugni and Passy 2001). The Bern Declaration is a fairly important SMO in the solidarity movement. Respondents were randomly selected from members, and drawn from Switzerland's two main linguistic regions (German-speaking and French-speaking).

Quantitative data emphasize relations between variables and allow for a statistical test of these relations. On the one hand, survey data enable us to confront hypotheses about the impact of networks and of the types of ties that lead to participation. On the other, the quantitative approach is limited in several ways. First, it cannot grasp the long process leading to individual participation, but only specific moments in an individual's life. The survey focuses on when individuals joined the organization and the moment when the survey was 
conducted, two windows to the members' life. What comes before and in between remains unavailable. Second, meanings are difficult to grasp with quantitative data. Life histories are better suited to capture structures of meanings. When individuals talk about themselves, they express the meaning of their practices and convey the subjective interpretation of their acts (Denzin 1989). This is important for the present purpose because social interactions structure meanings that influence individual perceptions, which in turn affect movement participation. Unlike survey data, furthermore, life histories also allow us to take seriously temporal experience. They capture past experiences, present feelings, and future hopes of individuals. They convey an individual's whole life, not just narrow windows. With life histories we are able to see the individual-life dynamics, which are crucial for understanding the processes of movement participation. Of course, qualitative methods have their weaknesses too, most significantly limits on generalizing the findings due to the limited number of interviews. This weakness is compensated by the complimentary use of qualitative and quantitative data.

Because both types of data were collected after individuals had joined the organization, they face the problem of retrospective bias from memory distortion. Social psychologists tell us that memory fades and recalls are selective (e.g., Baddeley 1979). Moreover, memory distortions vary according to the age of individuals and the nature of experiences. Individuals recall past events by reinterpreting them according to their present experiences, often with the aim of maintaining social desirability and reducing cognitive dissonance. For all these reasons, retrospective data face validity and reliability problems. For the analysis of individual participation, a better research design would be to interview individuals before and after they joined the protest, a difficult strategy in non-experimental settings because it's impossible to identify individuals who will join the protest. Very few scholars have been lucky enough to be able to conduct a before-and-after research design (see Klandermans and Oegema 1987; McAdam 1988).

The problem of retrospective bias is more serious for surveys than for life histories, but there are several reasons for confidence in our data. First, most of our findings are consistent with previous studies, specifically with those with a before-and-after research design. For example, the determining role of social and cultural characteristics, as well as social networks in the process of individual participation, is consistent with other studies. Second, according to empirical tests conducted by Coen van Rij (1994) in his study of trade-union participation, the reliability problem is less dramatic than one might think. Coen van Rij tested the reliability of a variety of questions, and found that the variation in responses was rather low for factual information (year of joining a trade union): 46 percent of trade unionists give the same response when they are interviewed twice and in 25 percent of the cases there is a variation of only one year in their responses. He found similar results for attitudes (towards the trade unions): 92 percent of trade unionists display consistent answers between surveys conducted at different point in time. Similar to Alwin and Krosnick (1991), Coen van Rij argues that the reliability of retrospective data is not much lower than that of comparable nonretrospective questions. He thus opposes scholars such as Smith (1984: 647) who think that "attitude recall is an inherently weak foundation for social science research." The use of retrospective data, on the other hand, is less problematic for life histories. For through life histories we want precisely to grasp meaning structures that result from a reinterpretation of past experiences and feelings (Denzin 1989).

My aim in this study is to understand how networks influence different levels of participation-a "black box in the study of social movements" (Barkan, Cohn, and Whitbaker 1995: 114)-instead of the mere fact of participation. The umbrella concept of participation covers various levels of commitment to social movements, which imply different degrees of effort. Scholars usually focus on participation as such rather than on its diverse forms (for exceptions see Barkan et al. 1995; Klandermans 1997; Kriesi 1993; McAdam 1988; Oliver 
1984). To measure participation intensity, I first focus on the notion of effort, as operationalized by Oliver and Marwell (1992). This distinguishes between members who "give time" and those who "give money." It distinguishes people who actively participate by spending time in an SMO from those who remain passive and limit themselves to financial support. I then attempt to distinguish between levels of participation among activists in SMOs. Klandermans's (1997) concept of duration offers a way to distinguish two levels of participation among activists: those who are irregularly active (by collaborating to a specific campaign or participating in annual meetings), and those who participate on a regular basis. We are left with three different levels of participation and the corresponding categories of members: subscribers (passive members who contribute financially to the organization), adherents (active members), and activists (regularly active members).

\section{THE SOCIALIZATION FUNCTION OF SOCIAL NETWORKS}

The first function of social networks in the process of individual participation is a cultural function. The actors' embeddedness in social networks shapes their identities and provides them with a social and political consciousness that allows them to come ideologically closer to a given political issue. Cultural orientation is not a simple reflection of social position, but develops in a web of social interactions. Social networks in which actors are interacting convey meanings-symbols, rituals, narratives - that build and solidify identities and shape the actors' cognitive frames. This allows them to seize and interpret the social reality and define a set of actions that leads them to get involved in this perceived reality (Somers 1992). Once integrated in socializing networks, individuals find themselves in an interactive structure that enables them to define and redefine their interpretive frames about a given protest issue. By fostering identification with certain political issues, this network function forms the initial condition for individual's framing of the movement (McAdam and Paulsen 1993; Snow et al. 1986). In other words, this function of networks creates a political consciousness and an initial disposition to participate.

My hypothesis is not that networks are the only channels for socializing individuals to a specific protest issue, but rather that the embeddedness in formal (organizational) or informal (interpersonal) networks that are close to that issue facilitates the emergence of a political consciousness related to certain issues and helps individuals to construct a salient identity which is an important cultural resource for joining the protest (e.g., McAdam and Paulsen 1993; Melucci 1996). As a corollary, I also argue that the more strongly individuals are socialized and identify with a protest issue, the more intensively they will participate in a social movement. Following McAdam and Paulsen (1993), I further hypothesize that people who do not have major countervailing embeddedness, that is, whose embeddedness is salient and meaningful, participate at higher levels. In contrast, people who have multiple embeddedness-that is, who have competing identities-will engage at a lower level.

The first hypothesis is confirmed by the survey data. Before they joined the Bern Declaration, members were embedded in a dense social network (See Appendices A and B for covariates and descriptive statistics). Fifty-nine percent of the respondents belonged to formal networks and most were embedded in more than one. Nevertheless, this formal embeddedness was culturally homogeneous, as most members belonged to either religious (both Catholic and Protestant) or leftist (specifically new left) networks, or both. These two networks form a social space of socialization and identity building for prospective members. In addition, members were deeply rooted in informal networks connected with the protest issue. Ninety percent of the respondents had friends, relatives, or acquaintances who were either ideologically close to the political issue or already committed to the solidarity movement. Although the variable I use mixes informal embeddedness before and after participation (and 
Table 1. The Impact of Socialization and Structural-Connection Functions on Participation Levels (Multiple Regression).

\begin{tabular}{|l|c|c|c|c|}
\hline & $\begin{array}{c}\text { Model 1 } \\
\text { Beta }\end{array}$ & $\begin{array}{c}\text { Model 2 } \\
\text { Beta }\end{array}$ & $\begin{array}{c}\text { Model 3 } \\
\text { Beta }\end{array}$ & $\begin{array}{c}\text { Model 4 } \\
\text { Beta }\end{array}$ \\
\hline Socialization function & & & & \\
Formal networks & -.02 & - & - & -.01 \\
$\begin{array}{l}\text { Embeddedness in formal networks (others) } \\
\text { Embeddedness in networks close to the movement }\end{array}$ & $.15^{* * *}$ & - & - & $.16^{* *}$ \\
$\begin{array}{l}\text { Informal networks } \\
\text { Embeddedness in informal networks }\end{array}$ & $.18^{* * *}$ & - & - & $.12^{* *}$ \\
Structural-connection function & & & & \\
Formal networks & - & .07 & .07 & .04 \\
Recruited by an organization & & & & \\
Informal networks & - & $.24 * * *$ & .05 & .08 \\
Recruited by a Bern Declaration member & - & & -.06 & -.08 \\
Recruited by a subscriber & - & & .01 & -.01 \\
Recruited by an adherent & - & & $.29^{* * *}$ & $.25^{* * *}$ \\
Recruited by an activist & - & & .00 & .01 \\
Recruited through weak ties & - & & $.12^{* *}$ & $.12^{*}$ \\
Recruited through strong acquired ties & - & & $-.09 *$ & -.07 \\
Recruited through strong ascriptive ties & $\mathrm{R} 2=.06$ & $\mathrm{R} 2=.07$ & $\mathrm{R} 2=.16$ & $\mathrm{R} 2=.21$ \\
\hline
\end{tabular}

$* \mathrm{P}=.05, * * \mathrm{P}=.01, * * * \mathrm{P}=.001$.

embeddedness is likely to increase after one becomes engaged), this result remains important. We can reasonably assume that few members do not have any kind of embeddedness (formal or informal) that socializes them to the protest issue and helps them to participation-facilitating identities. Thus, this result suggests that prior embeddedness produces initial dispositions that, in turn, provide a starting point for movement involvement.

As I have argued above, the incorporation into networks close to a social movement produces cultural proximity between an individual and the movement, and hence affects the intensity of participation. Individuals embedded in formal networks that are culturally close to the Bern Declaration should be more conscious of the issues raised by this organization and, as a result, more inclined to participate in it. Table 1 (model 1) confirms this hypothesis. The embeddedness of individuals in family and religious networks, which are historically and ideologically close to the solidarity movement (Passy 1998, Passy and Giugni 2001), pushed prospective members to join the Bern Declaration at a higher level of participation. In addition, as table 1 makes clear, the level of participation also depends from the embeddedness in informal networks. Interpersonal networks of friends, acquaintances, or relatives who are close to or involved in the solidarity movement increase the likelihood that one will join the organization with a high level of participation.

Life histories confirm the results of the survey, but allow us to make a step forward by showing how the duration of network socialization creates a strong political awareness and identification with movement issues, and how countervailing identities influence participation levels. If we look at the members' personal trajectories, we can see what structures of meanings arise from socialization and identity formation processes, and how they affect participation intensity. The life histories used here include all three levels of participation included in my study: activists (Yves, Josette, François, Maria Luisa, and Véronique), adherents (Stéphane, Pascal, and Sylvain), and subscribers (Bijan, Aimée, and Pasqualine). These respondents were selected randomly from a Bern Declaration membership list. 
All the activists I interviewed had a long and intense embeddedness in social networks culturally close to the solidarity movement, above all in religious and leftist networks. Moreover, they were embedded in a dense informal network open to development-aid issues. This embeddedness put individuals in a space of intense social interactions that socialized and encouraged identification with social injustices in third-world countries. In addition, social relations (formal or informal) produce meanings that help individuals to relate a protest issue to their personal life. In the words of one of the activists:

I lived the North/South cleavage as a fundamental injustice-right or wrong -but for me the deep injustice was really there. For me, it was the place where the world was really upside down [...] I lived that as something that we couldn't bear. [...] I think what has played a big role in my life are [Christian] summer camps [...] I think that has marked me for the lifetime... . (François)

Adherents followed a different path of socialization. First, their social embeddedness was shorter and more diversified. Second, the meanings arising from their socialization were less central in their life. Unlike activists, who were integrated in a coherent interactive space, the adherents I interviewed were embedded in competing networks that prevented the full development of a political identity based on development-aid issues. Countervailing networks led them to be open to other political issues such as peace, ecology, and unionism. For example, Sylvain says, "I am in some way a son of ecology," and never refers to the solidarity movement. The social interactions of adherents introduced other, higher-ranking identities to their hierarchy of social identities. They did not develop a sufficiently strong political consciousness towards the movement's issues to become activists.

Finally, subscribers followed yet a different socialization trajectory. They were not embedded in formal networks that could socialize them to the issues raised by the solidarity movement. Of course, they were embedded in networks, but they had no links with the movement. The only embeddedness related to it was informal. The three subscribers I interviewed had been socialized through their informal networks by relatives. Their socialization remained weak and superficial. Consequently, the structure of meanings arising from these social interactions placed development-aid issues in the periphery of their life world. In the words of one respondent: "It doesn't resonate enough [...] It's not because of lack of interest..." (Bijan).

\section{THE STRUCTURAL-CONNECTION FUNCTION OF SOCIAL NETWORKS}

As Ajzen and Fishbein (1980) point out, collective action is "nonvolitional behavior," meaning that the simple willingness to become active is not a sufficient condition; people still need opportunities for involvement. Social networks bridge the gap between actors who are culturally disposed to a political issue-and thus potentially mobilizable-and SMO participation opportunities. Networks thus mediate mobilization opportunities by connecting prospective participants in and allowing them to convert their political consciousness into action.

A number of studies have shown that the linkage between movement organizations and prospective participants is more likely to occur through informal interpersonal ties than through formal organizational ties (della Porta 1988; Gould 1995; McAdam 1986; McAdam and Paulsen 1993). Accordingly, I hypothesize that individuals who have social ties with people already involved in a movement organization are more likely become involved in that organization. Furthermore, because the type of interaction yields different structures of meaning about political commitment, I expect that the intensity of participation will vary according 
to the nature of the ties that link prospective members and their recruiters. More specifically, I first argue that, contrary to Granovetter's (1973) well known theory of weak ties in the labor market, strong ties have a crucial impact on participation in social movements because they provide individuals with trust. As Pizzorno (1986) has pointed out, trust is critical to understanding political behavior in situations of uncertainty. Before they join a movement organization, people are often in a situation of uncertainty because they lack information. Recruiters are usually the main channels for conveying knowledge about the protest. When recruiters are close friends (as opposed to acquaintances), potential participants tend to trust them and to be convinced that a particular SMO is the right one for converting their political interests into a strong degree of commitment. Second, I assume that the recruiter's level of participation in the organization affects that of prospective members: the higher the intensity of engagement of recruiters, the stronger the commitment of newcomers. For centrally located recruiters are more apt to reduce the uncertainty emphasized by Pizzorno. Furthermore, core activists usually are "true believers" who can better convince new members to contribute as strongly as possible to the organization's activities.

The survey data supports the first hypothesis. Seventy-nine percent of the members of the Bern Declaration have been recruited through social networks: 35 percent through formal and 44 percent through informal ties. The latter include 37 percent of ties consisting mainly of informal contacts with individuals who were already involved in the organization. Although formal networks (in the case of the Bern Declaration churches were central) play a greater role than it is usually supposed in the literature, informal ties constitute the most important linkage between prospective members and the opportunity of mobilization. As table 1 shows, they lead to a higher level of participation (model 2). However, it is more the nature of the interaction that influences the level of commitment (model 3) to the Bern Declaration than interpersonal networks in general. First, to be recruited by a close friend (strong acquired ties) leads to strong activism. By contrast, recruitment through family ties (strong ascriptive ties) leads to lower levels of participation, while recruitment by acquaintances (weak ties) does not seem to affect the intensity of participation. Thus, Granovetter's (1973) hypothesis on the strength of weak ties is not confirmed in the case of differential participation, which is in line with previous studies of social movements (Kriesi 1993; Marwell and Oliver 1988). Second, table 1 confirms that the level of participation depends on the position of the recruiter within the organization. Those who have been recruited by a core activist joined the organization at the highest level of commitment. Indeed, as the table's last column of the table indicates, this type of tie is the most important in the explanation of the intensity of participation (model 4).

While my hypotheses regarding this function of social networks are supported by the survey data, we must turn to life histories to fully understand why certain types of ties lead to more intensive participation. What is the structure of meanings that arises from these interactions? First of all, the interviews confirm that all activists were structurally connected to mobilization opportunities through close friends who were strongly involved in the organization. However, in addition to recruiters being close friends, the recruiters were important to prospective member because they trusted and admired them.

I had the impression of living with exceptional people.... I don't know if they are that exceptional, but in any case I met them in the camps, therefore it's people who I trusted [...] Gradually, I found myself in a vigil for the famous mothers of Buenos Aires, and it's there that I met Charles, whom I knew from the summer camps, and it's there that he plugged me into the Bern Declaration. I think I knew that the Bern Declaration newspaper existed-I must have seen it in the school library-but, well, I didn't knew 
much! And it's there that he plugged me into that, by telling me that they

were a group et cetera. It began like that. (François)

François, much like the other activists, trusted his recruiter. While they usually knew virtually nothing about the organization, they joined it with a high level of participation because their recruiters provided them with the trust necessary to convert their political awareness into action. Maria Luisa, for example, joined the Bern Declaration, even though she did not know much about it because a good friend told her that this organization was similar to those she used to be involved in when she was active in the student movement. Because she trusted her friend, she decided to put a lot of energy into the organization.

The meanings carried by the recruitment process are different for the other two categories of members. The adherent's recruiters are not close friends, but rather acquaintances or neighbors. The process involves a simple connection to participation opportunities whereby mediators provide information about the organization's existence. This kind of interaction is less meaningful than in the case of activists. According to one respondent, "I knew that Julien got into the Bern Declaration; we weren't friends, we knew each other a little bit through other friends; and then, I saw some issues of the Bern Declaration newspaper..." (Sylvain)

The structure of meanings carried in the interaction of subscribers with their recruiters is yet a different one. Confirming the previous findings (e.g., Kriesi 1993), the subscribers I interviewed were brought to the Bern Declaration through ascriptive ties, either a brother or a partner made the link between them and the organization. As I mentioned above, these members are only superficially socialized to the protest issues raised by the organization, which they joined because a family member convinced them to do so. The meaning structure conveyed here sounds like a moral obligation :

It's clear that without my little brother, I wouldn't be in the Bern Declaration! I wouldn't pay the fees. When he started, it's clear that the first thing was, "Do you want the Bern Declaration newspaper?" And then it was, "Do you want to become member?" Obviously, I wasn't going to say no... [laugh].” (Pasqualine)

\section{THE DECISION-SHAPING FUNCTION OF SOCIAL NETWORKS}

The decision-shaping function of networks is an important one for social movement theory because it links the structural location of actors to their individual preferences, bridging the gap between structure and agency. Social relations create and sustain a structure of meanings that contributes to the definition of individual perceptions about political commitment. Perceptions change according to both external events and events occurring in individuals' lives, especially everyday-life interactions that are largely shaped by social networks. Here, preferences are established by interpreting past experiences in light of present interactions. Furthermore, as Pizzorno (1996) points out, these interpretations are further redefined as they are communicated and interpreted. Thus, a two-way process occurs in that networks produce meanings that are integrated into the self and these meanings are redefined and elaborated through communication to others in these networks.

I include in the model three types of individual perceptions that have been stressed by previous collective action studies: the individual and the collective effectiveness of the action (Klandermans 1984, 1997; Marwell and Oliver 1993; McAdam 1982, 1986; Oliver 1984; Opp 1989), the ability of political authorities to solve the problem at hand (Piven and Cloward 1977), and personal availability, that is, the amount of time at one's disposal to be 
devoted to collective action (McAdam 1986; Marwell and Oliver 1993). In the latter case, I consider as a perception only the subjective availability, the objective one being a factual aspect. I do not take into account a fourth type of perception-the assessment of risks involved in collective action (Hirsch 1990, McAdam 1986) - because participation in a moderate and reformist organizations such as the Bern Declaration carries virtually no risks.

One way to assess the decision-shaping function of networks is to use LISREL to determine the indirect effect of networks on individual participation. ${ }^{2}$ This method is somewhat artificial because it uses a static design to analyze a dynamic process. However, using indicators of networks measured before engagement in the Bern Declaration (t1) and perceptions measured after one has become engaged (t2), approximates this function and offers an illustration of the relationships rather than a real test of the theory. In contrast, life histories are more suitable for evaluating the role of networks on individual perceptions. However, because social interactions continuously shape individual perceptions, it is not easy to capture systematically these effects with in-depth interviews. In spite of these limitations, combining these two methods provides an adequate illustration of the decision-shaping function of networks.

The LISREL model presented in figure 1 shows that the full set of perceptions is significantly shaped by social networks, except for subjective availability. ${ }^{3}$ Table 2 , which sum-

Figure 1. LISREL Estimates of Structural Equations Model of Social Movement Participation

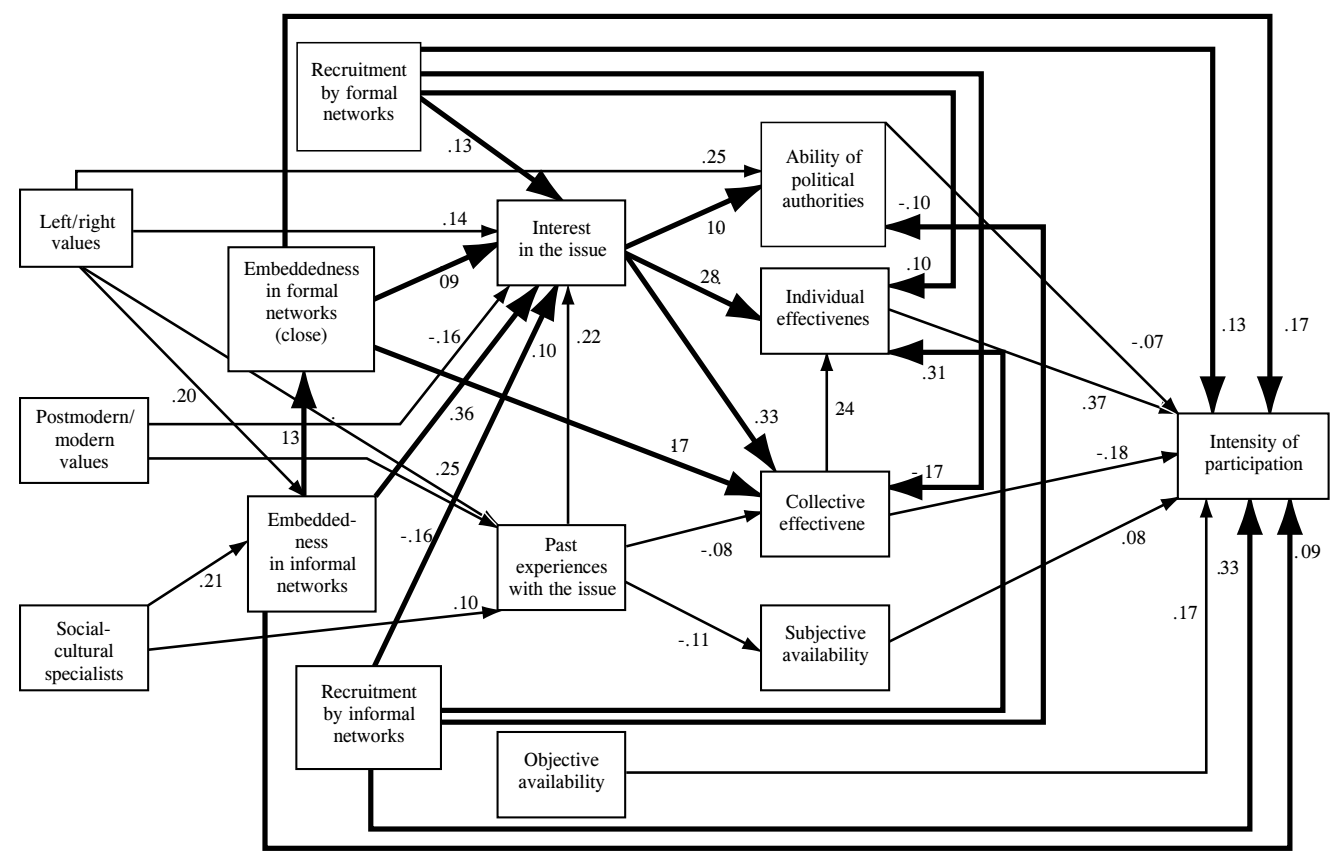

Note: Degrees of freedom $=147 ;$ Chi Square $=413.93 ;$ goodness of fit $=.949 ;$ Probability $=0.00$

2 To evaluate this function of social networks is not an easy task. Quantitatively, panel surveys are the most appropriate method because they offer the advantage of measuring interactions at $\mathrm{t} 1$ and evaluate their effect at $\mathrm{t} 2$. Unfortunately, I do not have this kind of data.

3 To keep the model readable, figure 1 shows only statistically significant coefficients. The probability test $(\mathrm{P})$ of the model is not statistically significant. However, if the Chi square/degree of freedom ratio varies between 1 and 3 , the model can nevertheless be accepted. The number of variables and their measure quality (mainly attitudes and evaluations) weaken the test of significance considerably. However, when we reduce the number of variables in the model by removing the social-cultural ones, which have an indirect effect on the dependent variable, the model becomes statistically significant. 
marizes the impact of networks on individual perceptions and on differential participation yielded by the LISREL model, shows that the perception of individual effectiveness is affected by the interactions of prospective members with their recruiters. The interaction with their recruiters tends then to substantially increase the sense that their participation to the protest is useful to bring social change. Thus, indirectly but strongly, recruiters influence the level of SMO participation. By contrast, the perception of the Bern Declaration's effectiveness in improving North-South imbalances is affected by the socialization of prospective participants in formal networks, while their connection to the organization through formal networks tends to reduce this perception. This might be due to the fact that these interactions push participants to be more realistic about the impact of solidarity organizations on global imbalances. Similarly, the perception of the ability of political authorities to solve problems pertaining to development aid is influenced by the interactions between prospective participants and their recruiters, which push participants to be more optimistic about the ability of authorities to solve these kinds of problems.

Table 2. Summary of Network Effects on Individual Participation based on LISREL Analysis (Standardized Solutions)

\begin{tabular}{|l|c|c|c|c|c|}
\hline & $\begin{array}{c}\text { Socialization } \\
\text { by formal } \\
\text { networks }\end{array}$ & $\begin{array}{c}\text { Socialization } \\
\text { by informal } \\
\text { networks }\end{array}$ & $\begin{array}{c}\text { Recruited } \\
\text { by formal } \\
\text { networks }\end{array}$ & $\begin{array}{c}\text { Recruited } \\
\text { by informal } \\
\text { networks }\end{array}$ & Interest \\
\hline Individual effectiveness & $\mathrm{ns}$ & $\mathrm{ns}$ & .10 & .31 & .28 \\
Collective effectiveness & .17 & $\mathrm{~ns}$ & -.17 & $\mathrm{~ns}$ & .33 \\
Ability of political authorities & $\mathrm{ns}$ & $\mathrm{ns}$ & $\mathrm{ns}$ & -.10 & .10 \\
Subjective availability & $\mathrm{ns}$ & $\mathrm{ns}$ & $\mathrm{ns}$ & $\mathrm{ns}$ & $\mathrm{ns}$ \\
Interest & .09 & .36 & .13 & .10 & - \\
\hline
\end{tabular}

The LISREL analysis shows that the effectiveness of individual commitment is largely a perception that is strongly shaped by social networks. Figure 1 shows that connection to mobilization opportunities through an activist positively affects this perception, which in turn leads individuals to the highest participation level. Also, social networks affect the interest in the political issue. As Kim and Bearman (1997) underline, interests are constructed, not given a priori. While the interest in the political issue is also a perception that is highly shaped by social interactions, the interesting point is that political interests strongly affect other individual perceptions (table 2, last right-hand column). In fact, political interest shapes the perception of individual effectiveness, perception of organizational effectiveness, and perception political authorities' ability to effect social change. These three types of perceptions are thus directly shaped by social networks, but also indirectly via the impact of the interest in the issue. We then see that the decision-shaping function of social networks is widespread.

The LISREL analysis shows further that, from the three sets of perceptions, individual and collective effectiveness are the best predictors of the intensity of participation. However, while the former positively affects the level of participation, the latter leads people to join the organization at the lowest level of commitment. In the remainder of this section I focus on these two aspects.

To begin with, the perception of collective effectiveness varies across the three types of members according to the nature and the modalities of the social interactions prior to engagement. For activists, the perception that social movements matter is the result of a long phase of network socialization during which they gradually became convinced that ordinary citizens can do something. For example, Yves became aware of this while he was involved in Christian networks and met missionaries working in third-world countries. He slowly understood that organized action could have positive effects. In his own words, "I think it's impor- 
tant to bring a brick to the building. [...] Surely the world would get even worse if there weren't all these people who have begun to move." The same happened with the other activists. Maria Luisa also developed this perception during her involvement in Christian networks and, later on, in radical-leftist networks. She felt that, "one must change the world; we are here for that." Véronique came to have the same perception by living the successes and failures of the Christian networks in which she was embedded. She was aware that this type of citizen mobilization would bring changes, be they only minor ones. She expressed this with the metaphor, "Rivers are made of water drops."

These observations are consistent with table 2, which demonstrates that socialization in formal networks shapes a feeling of collective effectiveness. However, prospective activists do not overestimate the ability of these organizations to redress North-South imbalances. The contributions of these organizations to such a huge task are "water drops," as Véronique said. While adherents and subscribers also feel that social movement organizations-specifically the Bern Declaration-are instrumental in bringing about social change, they tend to overrate their effectiveness. The data from the survey stress in fact that adherents and, above all, subscribers have a more positive perception of collective effectiveness than activists. This perception is acquired in part thanks to social interaction between them and their recruiters. According to one respondent, "It's by the intermediary of Caroline that I got to know the Bern Declaration. The boycott actions, etc. [...] They do a good job." (Bijan)

During Bijan's interview he kept saying that the organization did a good job. He explained that he previously knew nothing about it and that it is his recruiter who informed him about its activities. We can interpret this as suggesting that adherents and subscribers tend to have low issue socialization and weak political interest; and that recruiters must emphasize (and probably overrate) the organization's effectiveness in order to convince prospective members to participate or financially contribute.

In addition to the feeling that the organization matters, prospective members acquired the perception that their own participation is helpful. Again, there are substantial differences between activists and the other two types of members. While the activists' definition of collective effectiveness is partly built via formal network embeddedness, it is only when they connected with the Bern Declaration through a recruiter that their perception of individual effectiveness becomes a key factor in greater participation in the SMO. Recruiters strongly influence this perception, a result that is consistent with the findings in table 2. For example, Maria Luisa was connected to mobilization opportunities through a very close friend involved in the organization. She stated that in order to convince her to join the Bern Declaration, her friend told her, "Come on, come to the Bern Declaration, it's the only [real] movement of resistance since ' 68 . We do some good things." The reference to ' 68 reflects Maria Luisa's deep involvement in the 1968 student movement and her discouragement when it demobilized. Maria Luisa stated that joining the Bern Declaration was a way to pursue her ideals about social transformation. Her friend's message was a clear appeal intended to increase Maria Luisa's perceived effectiveness.

The other four activists had similar experiences before they joined the Bern Declaration. Recruiters stressed how helpful their participation would be. For example, a good friend convinced Josette to join by presenting it as one of the only groups in town that worked on North-South inequality, and that it stressed the responsibility of industrialized countries. He explained that the Bern Declaration aims to put the Swiss government and private enterprises under pressure so that they change their attitude towards third-world countries. Josette stated that she was so impressed by these tactics that she had to join the organization.

What I appreciated was that they were making the link [between the North and the South]. What we do here is so that things change further. It's not 
only giving money to create a cooperative or something else, which is pretty nice, but what does it change?

While recruiters who were structurally connected to prospective SMO participants succeeded in creating a positive feeling of individual effectiveness in activists, they failed to do so in the other two types of members. Adherents and, above all, subscribers did not perceive their own commitment as being very helpful to the cause. Bijan put that quite straightforwardly: "I don't have the necessary competencies to do a good job." My interviews indicate that recruiters gave adherents and subscribers a strong sense that the organization could bring about social change, but not a feeling that their own contribution could help.

Here again we see how social relations intervene in the definition of individual perceptions. Interactions create meanings that help prospective members to decide to convert their political consciousness into action. Social relations significantly affect how individuals define and redefine perceptions-before joining a movement, during participation, and afterwards. As I have shown elsewhere (Passy 1998; Passy and Giugni 2000), in order to explain participation and disengagement over time we must look at the impact of social relations on individual perceptions. For example, when Yves began to have doubts about the effectiveness of his participation, his network of friends led him to positively redefine this perception and helped him to stabilize his level of commitment.

Well, to fight better, you must be pretty thoughtful. You must be rather sly. You need a lot of generosity. And there are moments when you are in good shape, [and] moments when you are less in a good shape and you can do less. (Interviewer: Have you felt these cycles in your engagements?) Yeah, yeah...But I was lucky to always have people around me who were rather motivated. [...] It's clear that a guy like Charles is a guy who stimulates....

In contrast, once individuals lose the social networks that brought them into action, they tend to gradually disengage. This occurred for three of the activists interviewed. For example, when Maria Luisa disconnected from the networks that brought her to political commitment, she began to perceive her participation as ineffective and useless:

I feel a very strong sense of ineffectiveness. When I look retrospectively at how we got excited and all what we have obtained; it's a little bit derisory after all. And I think the fatigue settles. [...] I don't feel effective being at the Bern Declaration today.

\section{CONCLUSION}

In this article I clarified the impact of social networks on individual social movement participation in two ways. On the one hand, I specified the mechanisms at work in the process of participation by pointing to three distinct network functions. First, networks intervene in the socialization and construction of identities. This occurs in the long run and contributes to the creation of the political potential of social movements. Here networks create an initial disposition to participate. The structure of meanings of individuals varies according to their trajectories of socialization and can bring them culturally closer to a given political issue. The second network function intervenes right before prospective members join a social movement organization by offering those who are culturally sensitive to the issue an opportunity to participate. In other words, networks create a link between the political potential and a movement organization. Most importantly, the types of ties involved in the relationship between re- 
cruiters and recruits define different structures of meanings, which affect the intensity of participation. Finally, networks intervene when people take the decision to join a movement organization. They influence the definition of individual preferences, which are important for decisions to participate, not only at the moment of joining a SMO but also during their participation. Again, networks shape the meanings of the action, which in turn affect both the level of participation and its stability over time.

On the other hand, my study is an attempt to link rational choice accounts, which stress the role of the actors' intentions, and structural accounts, which put forth the role of social networks as the structural context within which actions take place. These two theoretical perspectives are bridged by the third function of networks, namely, how networks shape human agency by shaping the definition of individual perceptions. As Emirbayer and Goodwin (1994: 1444) have pointed out, "the individual autonomy is itself a constructed phenomena; that is, individual autonomy is only made possible by the sheer multiplicity of structures [...] within which social actors are situated at any given moment." In other words, I tried to show that social interactions create islands of meaning that strongly affect the actors' decisions. Meanings are constructed through social relations and in turn affect individual action, in our case, movement participation. Networks too are socially constructed realities, but at the same time they contribute to the creation of meanings when individuals incorporate into their selfconcept these multiple social interactions and their past experiences, and make sense of them. In other words, as Georges Haldas writes in his essay, there is no neutral interaction (1998).

By following a constructivist perspective that seriously takes into account the role of meanings, this article also deals with the impact of cultural factors on participation in social movements. Although recent work has attempted to redress this situation, the field is still marked by a division between explanations that emphasize structural variables (e.g., Kriesi et al. 1995; McAdam 1982; Tarrow 1994; Tilly 1978) and others that stress cultural variables (e.g., Gamson 1992; Melucci 1996; Snow et al. 1986; Snow and Benford 1992). A similar opposition can be observed at the micro level of analysis. Structural accounts have underscored both the constraining effect of social positions on participation in social movements and the role of networks (e.g., della Porta 1988; Eder 1993; Kriesi 1993; Inglehart 1990; McAdam 1986), while cultural accounts have pointed to the impact of cognitive and emotional factors (e.g., Eyerman and Jamison 1991; Goodwin 1997; Jasper 1997; Klandermans 1997). A number of studies have recently pointed the need of reconciling cultural and structural explanations of social movements and individual participation in collective action (e.g., Diani 1996; Johnston and Klandermans 1995; Koopmans and Statham 1999; McAdam et al. 1996; Morris and Mueller 1992). This article has followed the way paved by these studies by paying a special attention to social networks as a possible way to link these two types of variables and explanations.

\section{APPENDIX A: OPERATIONALIZATION OF VARIABLES}

Intensity of participation (dependent variable):

A question was asked that included the range of activities carried within the BD: (1) to pay membership fees, (2) to subscribe to the annual fund raising, (3) to participate in campaigns, (4) to participate in the annual meeting, (5) to participate in the organization of campaigns on a regular basis, (6) to be a member of working groups, and (7) to be a member of the central committee. The first two activities only involve contributing financially to the organization, the following two imply active participation on an irregular basis, and the last three call for active and regular participation. The variable has three categories: 
a) Subscribers: activities 1,2 , or both;

b) Adherents: activities 3 or 4 but not more, regardless of whether they also carry activities 1 or 2;

c) Activists: activities 5, 6, 7, regardless of whether they also carry one or more of the other activities.

\section{Social networks:}

\section{1) Socialization}

- Formal networks. Question: "In the following list, are there organizations or movements to which you have belonged in the past?" List of types of organizations. Networks close to the movement are identified by religious and new social movement organizations. The latter include the following thematic areas: ecology, antinuclear, development aid, human rights, political asylum and immigration, antiracism, peace, women, gay and lesbian.

- Informal networks. Question: "Do your friends or acquaintances are engaged/interested in thirdworld questions?" Ordinal variable of increasing level of engagement/interest.

\section{2) Recruitment}

- Formal networks. Question: "Can you say how you came into contact with the Bern Declaration for the first time? Is it through...[list of potential recruiters]? I selected from this list formal networks, that is, recruitment through churches and organizations.

- Informal networks. Question: "Were there one or more persons you knew personally before you joined the $\mathrm{BD}$ (relative, friend, acquaintance), who were members and who incited you to join the organization?" I further specify the relation between recruiters and recruits according to two criteria:

a) The nature of the relationship: strong acquired ties (close friends), strong ascriptive ties (relatives), weak ties (acquaintances, colleagues, neighbors);

b) The level of involvement of recruiters in the BD (subscribers, adherents, activists).

\section{Individual-level variables:}

\section{1) Perceptions}

- Individual effectiveness. Question: "How do you evaluate the contribution of your engagement in the BD?" Ordinal variable of increasing effectiveness.

- Collective effectiveness. Question: "Do you think that the action of the BD is effective to ameliorate the situation of third-world countries?" Ordinal variable of increasing effectiveness.

- Ability of authorities to bring about social change. Question: "Here is a list of authorities, organizations, and citizen groups that worry about (or should worry about) the situation in third-world countries. Can you indicate to what extent these authorities, organizations, and citizen groups are, in your view, apt to ameliorate the situation of third-world countries?" I first created two intermediate dummy variables, one by aggregating respondents who think authorities (national or international) are either totally apt or quite apt to ameliorate the situation, the other by aggregating respondents who think that citizen organizations are. Then I created the dummy to be used in the analyses by combining these two intermediate variables. The latter equal one when respondents think that the authorities are not apt to ameliorate the situation, while the citizens organizations are.

- Subjective availability. Question: "Among the following reasons, which are the ones that can explain the fact that sometimes you do not engage or, more exactly, that you do not engage more?" Ordinal variable of increasing agreement with the reasons listed. I selected from the list the following reason: "my available time is limited."

- Interest in the issue. Question: "What role do third-world questions have in your life?" Ordinal variable of increasing importance.

2) Objective aspects

- Objective availability: percentage of time in paid employment. Categories: less than $30 \%, 30-50 \%$, $50-80 \%, 80-100 \%$.

- Previous contacts with the issue. Question: "What has pushed you to become active [related to thirdworld problems]." List of items. I selected from the list the following items:

a) "I am born/I lived in a third-world country";

b) "A journey in the third world";

c) "Friends or acquaintances coming from a third-world country". 


\section{APPENDIX B: DESCRIPTIVE STATISTICS OF VARIABLES}

\begin{tabular}{|l|c|c|c|c|c|}
\hline Variable & Type & Minimum & Maximum & Mean & $\begin{array}{c}\text { Standard } \\
\text { deviation }\end{array}$ \\
\hline Dependent variable & ordinal & 1 & 3 & 1.34 & .62 \\
Intensity of participation & & & & & \\
Social networks & & & & & \\
Socialization & ordinal & 0 & 2 & .54 & .60 \\
Formal networks close to the movement & ordinal & 0 & 7 & .52 & .98 \\
Other formal networks & ordinal & 1 & 4 & 2.51 & .90 \\
Informal networks & & & & & \\
Recruitement & dummy & 0 & 1 & .35 & .48 \\
Organization & dummy & 0 & 1 & .36 & .48 \\
BD member & dummy & 0 & 1 & .18 & .38 \\
Activist & dummy & 0 & 1 & .05 & .22 \\
Adherent & dummy & 0 & 1 & .13 & .34 \\
Subscriber & dummy & 0 & 1 & .14 & .35 \\
Strong acquired ties & dummy & 0 & 1 & .06 & .24 \\
Strong ascriptive ties & dummy & 0 & 1 & .17 & .37 \\
Weak ties & & & & & \\
Individual-level variables & & & & & \\
Perceptions & & & & \\
Interest in the issue & ordinal & 1 & 5 & 3.36 & .87 \\
Individual effectiveness & ordinal & 1 & 5 & 2.71 & 1.12 \\
Collective effectiveness & ordinal & 1 & 5 & 4.00 & .92 \\
Ability of political authorities & dummy & 0 & 1 & .47 & .50 \\
Subjective availability & ordinal & 1 & 5 & 1.87 & 1.17 \\
Objective aspects & & & & & \\
Objective availability & ordinal & 1 & 4 & 1.58 & .83 \\
Past experiences with the issues & dummy & 0 & 1 & .24 & .43 \\
\hline
\end{tabular}

\section{REFERENCES}

Ajzen, Icek, and Martin Fishbein, 1980. Understanding Attitudes and Predicting Social Behavior. Englewood Cliffs: Prentice Hall.

Alwin, Duan, and Jon Krosnick 1991. "The Reliability of Survey Attitude Measurement. The Influence of Question and Respondent Attributes." Sociological Methods and Research 20:139-81.

Andrews, Molly 1991. Lifetimes of Commitment. Cambridge University Press.

Baddeley, Alan 1979. "The Limitations of Human Memory: Implications for the Design of Retrospective Surveys." Pp.13-27 in Louis Moss and Harvey Goldstein (eds.) The Recall Methods in Social Surveys. London: University of London Institute of Education.

Barkan, Steven, Steven Cohn, and William Whitbaker 1995. "Beyond Recruitment: Predictors of Differential Participation in National Antihunger Organization.” Sociological Forum 10:113-33.

Calhoun, Craig 1989. "Protest in Beijing: The Conditions and Importance of the Chinese Student Movement of 1989." Partisan Review 56: 563-80.

Chong, Dennis 1991. Collective Action and the Civil Rights Movement. Chicago: University of Chicago Press.

Coen van Rij, Johann 1994. To Join or Not to Join. An Event-history Analysis of Trade-Union Membership in the Netherlands. PhD Thesis. University of Amsterdam.

della Porta, Donatella 1988. "Recruitment Processes in Clandestine Political Organizations: Italian Left-Wing Terrorism,” pp. 155-72 in Bert Klandermans, Hanspeter Kriesi and Sidney Tarrow 
(eds.) International Social Movement Research: From Structure to Action. Greenwich: JAI Press.

1995. Social Movements, Political Violence, and the State. A Comparative Analysis of Italy and Germany. Cambridge: Cambridge University Press.

Diani, Mario 1995. Green Networks. A Structural Analysis of the Italian Environmental Movement. Edinburgh: Edinburgh University Press.

. 1996. "Linking Mobilization Frames and Political Opportunities. Insights from Regional Populism in Italy." American Sociological Review 61: 1053-69.

Denzin, Norman K. 1989. Interpretive Biography. London: Sage.

Eder, Klaus 1993. The New Politics of Class. London: Sage.

Emirbayer, Mustafa, and Jeff Goodwin 1994. "Network Analysis, Culture, and the Problem of Agency." American Journal of Sociology 99: 1411-54.

Eyerman, Ron, and Andrew Jamison 1991. Social Movements. A Cognitive Approach. University Park: Pennsylvania State University Press.

Fernandez, Roberto, and Doug McAdam 1989. "Multiorganizational Fields and Recruitment to Social Movements." International Social Movement Research 2: 315-43.

Freeman, Jo 1973. “The Origins of the Women's' Liberation Movement.” American Journal of Sociology 78: 792-811.

Friedman, Debra, and Doug McAdam. 1992. "Collective Identity and Activism: Networks, Choices, and the Life of a Social Movement," pp. 156-73 in Aldon D. Morris and Carol McClurg Mueller (eds) Frontiers in Social Movement Theory. New Haven: Yale University Press.

Gamson, William A. 1992.”The Social Psychology of Collective Action,” Pp. 53-76 in Aldon D. Morris and Carol McClurg Mueller (eds.) Frontiers in Social Movement Theory. New Haven: Yale University Press.

Giugni, Marco 1998. "Review Essay: Structure and Culture in Social Movement Theory." Sociological Forum 13: 365-75.

Giugni, Marco and Florence Passy (eds) 2001. Political Altruism ? Boulder: Rowman and Littlefield.

Goodwin, Jeff 1997. "The Libidinal Constitution of a High-Risk Social Movement. Affectual Ties and Solidarity in the Huk Rebellion, 1946 to 1954." American Sociological Review 62: 53-69.

Gould, Roger V. 1993. "Collective Action and Network Structure." American Sociological Review 58: $182-96$.

. 1995. Insurgent Identities. Chicago: Chicago University Press.

Granovetter, Mark 1973. "The Strength of Weak Ties.” American Journal of Sociology 78: 1360-80.

Haldas, Georges 1998. Le livre des trois déserts. Regard-Nouvelle Cité.

Heckathorn, Douglas D. 1993. "Collective Action and Group Heterogeneity: Voluntary Provision Versus Selective Incentives." American Sociological Review 58: 249-68.

Hirsch, Eric L. 1990. "Sacrifice for the Cause: Group Processes, Recruitment, and Commitment in a Student Social Movement." American Sociological Review 55: 243-54.

Inglehart, Ronald 1990. "Values, Ideology, and Cognitive Mobilization in New Social Movements." Pp. 43-66 in Russel J. Dalton et Manfred Kuechler (eds.). Challenging the Political Order. Cambridge: Basil Blackwell.

Jasper, James M. 1997. The Art of Moral Protest. Chicago. Chicago University Press.

Johnston, Hank, and Bert Klandermans (eds.) 1995. Culture and Social Movements. Minneapolis: University of Minnesota Press.

Kim, Hyojoung, and Peter S. Bearman 1997. "The Structure and Dynamics of Movement Participation." American Sociological Review 62: 70-93.

Klandermans, Bert 1984. "Mobilization and Participation. Social-Psychological Expansions of resource Mobilization Theory." American Sociological Review 49: 583-600. .1997. The Social Psychology of Protest. Oxford: Blackwell.

Klandermans, Bert, and Dirk Oegema 1987. "Potentials, Networks, Motivations and Barriers: Steps Toward Participation in Social Movements.” American Sociological Review 52: 519-31. 
Koopmans, Ruud, and Paul Statham 1999. "Political Claims Analysis: Integrating Protest Event and Political Discourse Approaches." Mobilization 4: 203-221.

Kriesi, Hanspeter. 1993. Political Mobilization and Social Change. The Dutch Case in Comparative Perspective. Aldershot: Avebury.

Kriesi, Hanspeter, Ruud Koopmans, Jan Willem Duyvendak and Marco Giugni 1995. New Social Movements in Western Europe. Minneapolis: University of Minnesota Press.

Macy, Michael 1991. "Chains of Cooperation: Threshold Effects of Collective Action." American Sociological Review 56: 730-47.

Marwell, Gerald, and Pamela Oliver 1993. The Critical Mass in Collective Action. A Micro-Social Theory. Cambridge: Cambridge University Press.

Marwell, Gerald, Pamela Oliver, and Ralph Prahl 1988. "Social Networks and Collective Action. A Theory of Critical Mass. III." American Journal of Sociology 94: 502-34.

McAdam, Doug 1982. Political Process and the Development of Black Insurgency, 1930-1970. Chicago: University of Chicago Press.

.1986. "Recruitment to High Risk Activism: The Case of Freedom Summer." American Journal of Sociology 92: 64-90. . 1988. Freedom Summer. New York: Oxford University Press.

McAdam, Doug, and Ronelle Paulsen 1993. "Specifying the Relationship between Social Ties and Activism." American Journal of Sociology 99: 640-67.

McAdam, Doug, John D. McCarthy, and Mayer N. Zald (eds.) 1996. Comparative Perspectives on Social Movements: Political Opportunities, Mobilizing Structures, and Cultural Framings. Cambridge: Cambridge University Press.

Melucci, Alberto 1996. Challenging Codes. Cambridge: Cambridge University Press.

Morris, Aldon 1984. The Origins of the Civil Rights Movement. New York: Free Press.

Morris, Aldon D., and Carol McClurg Mueller (eds.) 1992. Frontiers in Social Movement Theory. New Haven: Yale University Press.

Mueller, Edward N., and Karl-Dieter Opp 1986. "Rational Choice and Rebellious Collective Action." American Political Science Review 80: 471-87.

Oberschall, Anthony 1973. Social Conflict and Social Movements. Englewood Cliffs: Prentice-Hall. . 1993. Social Movements. New Brunswick: Transaction Books.

Oliver, Pamela E. 1984. "If You Don't Do It, Nobody Will. Active and Token Contributions to Local Collective Action." American Sociological Review 49: 601-10. . 1988. "The Paradox of Group Size in Collective Action: A Theory of the Critical Mass. II." American Sociological Review 53: 1-8.

Oliver, Pamela E., and Gerald Marwell 1992. "Mobilizing Technologies for Collective Action”, pp. 251-73 in Aldon D. Morris and Carol McClurg Mueller (eds.), Frontiers in Social Movement Theory. New Haven: Yale University Press.

Oliver, Pamela E., Gerald Marwell, and Roy Texeira 1985. "A Theory of Critical Mass. I. Interdependence, Group Heterogeneity, and the Production of Collective Action." American Sociological Review 91: 522-56.

Olson, Mancur 1965. The Logic of Collective Action. Cambridge: Harvard University Press.

Opp, Karl-Dieter 1989. The Rationality of Political Protest. A Comparative Analysis of Rational Choice Theory. Boulder: Westview Press.

Passy, Florence 1998. L'action altruiste. Genève-Paris: Droz.

Passy, Florence, and Marco Giugni 2000. "Life-spheres, Networks, and Sustained Participation in Social Movements. A Phenomenological Approach to Political Commitment." Sociological Forum 15: 117-44.

Passy, Florence, and Marco Giugni 2001. "Social Networks and Individual Perceptions: Explaining Differential Participation in Social Movements." Sociological Forum 16: 123-53.

Pizzorno, Alessandro 1986. "Sur la rationalité du choix démocratique" Pp. 330-69 in Sur l'individualisme, P. Birnbaum and J. Leca (eds.) Paris: Presses de la FNSP. 
. 1996. "Decisioni o interazioni? La micro-decisione del cambiamento sociale." Rassegna italiana di sociologia 37: 107-32.

Piven, Frances Fox, and Richard A. Cloward 1977. Poor People's Movements. New York: Vintage.

Rosenthal, Naomi, Meryl Fingrutd, Michele Ethier, Roberta Karant, and David McDonald 1985. "Social Movements and Network Analysis: A Case Study of Nineteenth Century Women's Reform in New York State.” American Journal of Sociology 90: 1022-55.

Sandler, Todd 1992. Collective Action. Theory and Applications. Ann Arbor: University of Michigan Press.

Smith, Tom W. 1984. "Recalling Attitudes. An Analysis of Retrospective Questions on the 1982 GSS." Public Opinion Quarterly 48: 639-49.

Snow David, and Robert Benford 1992. "Master Frames and Cycles of Protest." Pp. 133-55 in Frontiers in Social Movement Theory, A, Morris and C. Mueller (eds.) New Haven: Yale University Press.

Snow, David, Louis Zurcher, and Sheldon Ekland-Olson 1980. "Social Networks and Social Movements: A Microstructural Approach to Differential Recruitment.” American Sociological Review 45: 787-801.

Snow, David, E. Burke Rochford, Steven Worden, and Robert Benford 1986. "Frame Alignment Processes, Micromobilization, and Movement Participation." American Sociological Review 51: 464-81.

Somers, Margaret R. 1992. "Narrativity, Narrative Identity, and Social Action: Rethinking English Working-Class Formation.” Social Science History 16: 591-630.

Tarrow, Sidney 1994. Power in Movement. Cambridge: Cambridge University Press.

Tilly, Charles 1978. From Mobilization to Revolution. Englewood Cliffs: Prentice-Hall.

White, Harrison C. 1992. Identity and Control. Princeton: Princeton University Press.

Whittier, Nancy 1995. Feminist Generations. The Persistence of the Radical Women's' Movement. Philadelphia: Temple University Press 